\title{
Triphenylphosphine Mediated Synthesis of Functionalized Benzo-Fused Coumarins from Some OH Acids and Dialkyl Acetylene Dicarboxylate
}

\author{
Bita Mohtat, ${ }^{1}$ Semiramis Nahavandian, ${ }^{1}$ Maryam Razaghi, ${ }^{1}$ \\ Saeedeh Farsijani, ${ }^{1}$ and Hoorieh Djahaniani ${ }^{2}$ \\ ${ }^{1}$ Chemistry Department, Karaj Branch, Islamic Azad University, P.O. Box 31485-313, Karaj, Iran \\ ${ }^{2}$ Chemistry Department, East Tehtan Branch, Islamic Azad University, P.O. Box 163-33955, Tehran, Iran
}

Correspondence should be addressed to Bita Mohtat; b_mohtat@yahoo.com

Received 6 February 2013; Accepted 22 July 2013

Academic Editor: Silvia Mari

Copyright (C) 2013 Bita Mohtat et al. This is an open access article distributed under the Creative Commons Attribution License, which permits unrestricted use, distribution, and reproduction in any medium, provided the original work is properly cited.

Benzo-fused coumarins are prepared from 4-quinolinol by treatment with $\mathrm{PPh}_{3}$ and dialkyl acetylenedicarboxylate. Angular coumarins are prepared from 3-isoquinolinol and 7-hydroxyl coumarine with $\mathrm{PPh}_{3}$ and dialkyl acetylenedicarboxylate.

\section{Introduction}

Coumarins comprise a very large class of compounds found throughout the plant kingdom [1]. The bioactivity of coumarin and more complex related derivatives appears to be based on the coumarin nucleus [2,3]. Coumarin compounds can display anticancer, anticoagulant, antimicrobial, antiinflammatory, and antioxidant activities [4-8].

In addition, as an important class of organic heterocyclic dyes, coumarin derivatives exhibit unique photochemical and photophysical properties, which render them useful in a variety of applications such as optical brighteners, laser dyes, nonlinear optical chromophores, solar energy collectors, fluorescent labels and probes in biology and medicine, and two-photon absorption (TPA) materials [9-12].

Coumarins have been synthesized by several methods [13-18]. In the interest of synthesizing new coumarin ring systems for possible evaluation as biologically active compounds, we have described a synthesis of carboxymethyl coumarins from 3-hydroxyl pyridine [19], carboxylic systems [19-22], we wish to report here the synthesis of some benzofused coumarins. The preparations of coumarins are depicted in Schemes 1, 2, and 3.

\section{Experimental}

2.1. General. Compounds $\mathbf{1}, \mathbf{2}$ and $\mathrm{Ph}_{3} \mathrm{P}$ were obtained from Fluka and were used without further purification. M. p. Electrothermal-9100 apparatus. IR Spectra: Shimadzu IR460 spectrometer. ${ }^{1} \mathrm{H}$ - and ${ }^{13} \mathrm{C}$ NMR spectra: Bruker DRX300 AVANCE instrument; in $\mathrm{CDCl}_{3}$ at 300 and $75 \mathrm{MHz}$, respectively; $\delta$ in ppm. EI-MS $(70 \mathrm{eV})$ : Finnigan-MAT-8430 mass spectrometer, in $m / z$. Elemental analyses $(\mathrm{C}, \mathrm{H}, \mathrm{N})$ were performed with a Heraeus CHN-O-Rapid analyser.

2.2. General Procedure for the Preparation of Compound 3. To a stirred solution of $0.52 \mathrm{~g}$ of $\mathrm{Ph}_{3} \mathrm{P}(2 \mathrm{mmoL})$ and $0.28 \mathrm{~g}$ $\mathbf{1}(2 \mathrm{mmoL})$ in toluene $(10 \mathrm{~mL})$ was added dropwise a mixture of $2(2 \mathrm{mmoL})$ in toluene $(2 \mathrm{~mL})$ at room temperature over $5 \mathrm{~min}$. The reaction mixture was heated under reflux for $24 \mathrm{~h}$. The solvent was removed under reduced pressure, and the viscous residue was purified by column chromatography $\left(\mathrm{SiO}_{2}\right.$; hexane/AcOEt) to afford the pure adducts.

Methyl 2-Oxo-2H-pyrano[3,2-c]quinoline-4-carboxylate (4a). Yellow powder, $0.46 \mathrm{~g}(90 \%) ; \mathrm{mp} 119-121^{\circ} \mathrm{C}$; IR $(\mathrm{KBr})$ $\nu_{\max } / \mathrm{cm}^{-1}: 1744(\mathrm{C}=\mathrm{O}), 1625(\mathrm{C}=\mathrm{N}) ;{ }^{1} \mathrm{H} N M R(300 \mathrm{MHz}$, $\left.\mathrm{CDCl}_{3}\right): \delta 4.08(\mathrm{~s}, 3 \mathrm{H}, \mathrm{Me}), 7.09(\mathrm{~s}, 1 \mathrm{H}, \mathrm{CH}), 7.70$ 
<smiles></smiles>

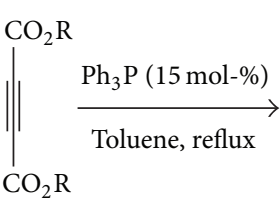
2

\begin{tabular}{c|c}
$\mathbf{2}$ & $\mathrm{R}$ \\
\hline $\mathbf{a}$ & $\mathrm{Me}$ \\
$\mathbf{b}$ & $\mathrm{Et}$ \\
$\mathbf{c}$ & $t-\mathrm{Bu}$
\end{tabular}

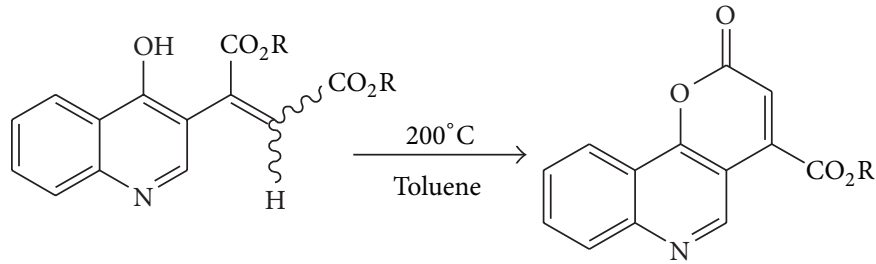

3

\begin{tabular}{c|cc}
$\mathbf{4}$ & $\mathrm{R}$ & Yield (\%) \\
\hline $\mathbf{a}$ & $\mathrm{Me}$ & 90 \\
$\mathbf{b}$ & $\mathrm{Et}$ & 77 \\
$\mathbf{c}$ & $t-\mathrm{Bu}$ & 72
\end{tabular}

Scheme 1: Typical procedure for compound 4.

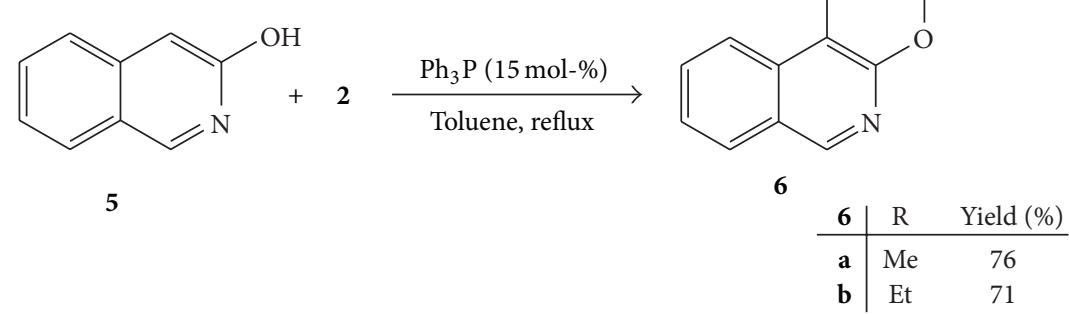

Scheme 2: Procedure for synthesis of compound 6.

$(\mathrm{t}, 1 \mathrm{H}, J=6.5 \mathrm{~Hz}, \mathrm{CH}) 7.88(\mathrm{t}, 1 \mathrm{H}, J=7.0, \mathrm{CH}), 8.15(\mathrm{~d}, 1 \mathrm{H}$, $J=8.4 \mathrm{~Hz}, \mathrm{CH}), 8.45(\mathrm{~d}, 1 \mathrm{H}, J=7.9 \mathrm{~Hz}, \mathrm{CH}), 9.71(\mathrm{~s}, 1 \mathrm{H}$, $\mathrm{CH}) .{ }^{13} \mathrm{C} \mathrm{NMR}\left(75 \mathrm{MHz}, \mathrm{CDCl}_{3}\right): \delta 53.6(\mathrm{Me}), 107.9(\mathrm{CH})$, $117.7(\mathrm{CH}), 119.6(\mathrm{CH}), 127.6(\mathrm{CH}), 129.3(\mathrm{C}), 132.4(\mathrm{CH}), 141.7$ $(\mathrm{CH}), 147.7(\mathrm{C}), 147.8(\mathrm{C}), 148.9(\mathrm{C}), 157.4(\mathrm{C}), 158.6(\mathrm{C}=\mathrm{O})$, $163.5(\mathrm{C}=\mathrm{O})$. MS (EI) $m / z: 255\left(\mathrm{M}^{+}, 98 \%\right), 227$ (57), $196(84)$, 140 (43). Anal. calcd for $\mathrm{C}_{14} \mathrm{H}_{9} \mathrm{NO}_{4}$ : C, 65.88; H, 3.55; N, 5.49; Found: C, 65.87; H, 3.57; N, 5.47.

Ethyl 2-Oxo-2H-pyrano[3,2-c]quinoline-4-carboxylate (4b). Yellow powder, $0.41 \mathrm{~g}(77 \%) ; \mathrm{mp} 128-130^{\circ} \mathrm{C}$. IR $(\mathrm{KBr})$ $v_{\max } / \mathrm{cm}^{-1}: 1740(\mathrm{C}=\mathrm{O}), 1634(\mathrm{C}=\mathrm{N}) ;{ }^{1} \mathrm{H}$ NMR $(300 \mathrm{MHz}$, $\left.\mathrm{CDCl}_{3}\right): \delta 1.47(\mathrm{t}, 3 \mathrm{H}, J=7.1 \mathrm{~Hz}, \mathrm{Me}), 4.54(\mathrm{q}, 2 \mathrm{H}, J=7.1 \mathrm{~Hz}$, $\mathrm{OCH}_{2}$ ), 7.09 (s, $\left.1 \mathrm{H}, \mathrm{CH}\right), 7.81(\mathrm{t}, 1 \mathrm{H}, J=7.3 \mathrm{~Hz}, \mathrm{CH}), 7.96$ $(\mathrm{t}, 1 \mathrm{H}, J=6.9, \mathrm{CH}), 8.14(\mathrm{~d}, 1 \mathrm{H}, J=8.4 \mathrm{~Hz}, \mathrm{CH}), 8.43(\mathrm{~d}$, $1 \mathrm{H}, J=8.3 \mathrm{~Hz}, \mathrm{CH}), 9.64(\mathrm{~s}, 1 \mathrm{H}, \mathrm{CH}) .{ }^{13} \mathrm{CNMR}(75 \mathrm{MHz}$, $\left.\mathrm{CDCl}_{3}\right): \delta 14.3(\mathrm{Me}), 63.5\left(\mathrm{OCH}_{2}\right), 107.9(\mathrm{CH}), 117.7(\mathrm{CH})$, $120.1(\mathrm{CH}), 127.6(\mathrm{CH}), 129.3(\mathrm{C}), 132.4(\mathrm{CH}), 141.7(\mathrm{CH})$, 147.7 (C), 147.8 (C), 148.9 (C), $157.4(\mathrm{C}), 158.6(\mathrm{C}=\mathrm{O}), 163.5$ (C=O). MS (EI) m/z: $255\left(\mathrm{M}^{+}, 98 \%\right), 196$ (72), 196 (69), 154 (100). Anal. calcd for $\mathrm{C}_{15} \mathrm{H}_{11} \mathrm{NO}_{4}$ : C, 66.91; H, 4.12; N, 5.20; Found: C, 66.94; H, 4.11; N, 5.19.

Tert-butyl 2-Oxo-2H-pyrano[3,2-c]quinoline-4-carboxylate (4c). Yellow powder, $0.43 \mathrm{~g}(72 \%) ; \mathrm{mp} 130-132^{\circ} \mathrm{C}$. IR $(\mathrm{KBr})$ $v_{\max } / \mathrm{cm}^{-1}: 1723(\mathrm{C}=\mathrm{O}), 1628(\mathrm{C}=\mathrm{N}) ;{ }^{1} \mathrm{H}$ NMR $(300 \mathrm{MHz}$, $\left.\mathrm{CDCl}_{3}\right): \delta 1.70(\mathrm{~s}, 9 \mathrm{H}, 3 \mathrm{Me}), 7.02(\mathrm{~s}, 1 \mathrm{H}, \mathrm{CH}), 7.80(\mathrm{t}, 1 \mathrm{H}$, $J=6.9 \mathrm{~Hz}, \mathrm{CH}), 7.95(\mathrm{t}, 1 \mathrm{H}, J=6.9, \mathrm{CH}), 8.13(\mathrm{~d}, 1 \mathrm{H}$, $J=8.4 \mathrm{~Hz}, \mathrm{CH}), 8.42(\mathrm{~d}, 1 \mathrm{H}, J=8.3 \mathrm{~Hz}, \mathrm{CH}), 9.60(\mathrm{~s}, 1 \mathrm{H}$,
$\mathrm{CH}) .{ }^{13} \mathrm{CNMR}\left(75 \mathrm{MHz}, \mathrm{CDCl}_{3}\right): \delta 28.1(3 \mathrm{Me}), 85.3(\mathrm{C})$, $107.9(\mathrm{CH}), 118.5(\mathrm{CH}), 119.5(\mathrm{CH}), 128.6(\mathrm{CH}), 130.3(\mathrm{C})$, $132.8(\mathrm{CH}), 141.7(\mathrm{CH}), 147.7(\mathrm{C}), 148.8(\mathrm{C}), 149.8(\mathrm{C}), 157.4$ (C), $159.3(\mathrm{C}=\mathrm{O}), 163.4(\mathrm{C}=\mathrm{O})$. MS (EI) $m / z: 255\left(\mathrm{M}^{+}, 98 \%\right)$, 269 (86), 196 (48), 57 (100). Anal. calcd for $\mathrm{C}_{17} \mathrm{H}_{15} \mathrm{NO}_{4}$ : C, $68.68 ; \mathrm{H}, 5.09 ; \mathrm{N}, 4.71$; Found: 68.70; H, 5.08; N, 4.69.

Methyl 3-Oxo-3H-pyrano[2,3-c]isoquinoline-1-carboxylate (6a). Yellow powder, $0.69 \mathrm{~g}(76 \%) ; \mathrm{mp} 105-107^{\circ} \mathrm{C}$. IR $(\mathrm{KBr})$ $v_{\max } / \mathrm{cm}^{-1}: 1733(\mathrm{C}=\mathrm{O}), 1651(\mathrm{C}=\mathrm{N}) ;{ }^{1} \mathrm{H}$ NMR $(300 \mathrm{MHz}$, $\left.\mathrm{CDCl}_{3}\right): \delta 4.04(\mathrm{~s}, 3 \mathrm{H}, \mathrm{Me}), 6.88(\mathrm{~s}, 1 \mathrm{H}, \mathrm{CH}), 7.55(\mathrm{t}, 1 \mathrm{H}$, $J=7.7 \mathrm{~Hz}, \mathrm{CH}), 7.67(\mathrm{t}, 1 \mathrm{H}, J=8.2 \mathrm{~Hz}, \mathrm{CH}), 7.70(\mathrm{~d}, 1 \mathrm{H}$, $J=8.1 \mathrm{~Hz}, \mathrm{CH}), 7.89(\mathrm{~d}, 1 \mathrm{H}, J=8.1 \mathrm{~Hz}, \mathrm{CH}), 9.24(\mathrm{~s}, 1 \mathrm{H}$, $\mathrm{CH}) .{ }^{13} \mathrm{CNMR}\left(75 \mathrm{MHz}, \mathrm{CDCl}_{3}\right): \delta 53.8(\mathrm{Me}), 110.3(\mathrm{C})$, $122.4(\mathrm{CH}), 123.0(\mathrm{CH}), 124.7(\mathrm{CH}), 126.3(\mathrm{CH}), 127.1(\mathrm{CH})$, 128.5 (C), $132.9(\mathrm{C}), 140.2(\mathrm{CH}), 143.6(\mathrm{C}), 158.1(\mathrm{C}), 164.0$ $(\mathrm{C}=\mathrm{O}), 166.4(\mathrm{C}=\mathrm{O})$. MS (EI) $m / z: 255\left(\mathrm{M}^{+}, 10 \%\right), 288(100)$, 204 (43), 189 (72), 61 (100). Anal. calcd for $\mathrm{C}_{14} \mathrm{H}_{9} \mathrm{NO}_{4}$ : C, 65.88; H, 3.55; N, 5.49; Found: C, 65.84; H, 3.56; N, 5.47.

Ethyl 3-Oxo-3H-pyrano[2,3-c]isoquinoline-1-carboxylate $(\boldsymbol{6 b})$. Yellow powder, $0.38 \mathrm{~g}(71 \%) ; \mathrm{mp} 110-112^{\circ} \mathrm{C}$. IR $(\mathrm{KBr})$ $v_{\max } / \mathrm{cm}^{-1}: 1739(\mathrm{C}=\mathrm{O}), 1636(\mathrm{C}=\mathrm{N}) ;{ }^{1} \mathrm{H}$ NMR $(300 \mathrm{MHz}$, $\left.\mathrm{CDCl}_{3}\right): \delta 1.43(\mathrm{t}, 3 \mathrm{H}, J=7.1 \mathrm{~Hz}, \mathrm{Me}), 4.35(\mathrm{q}, 2 \mathrm{H}, J=7.1 \mathrm{~Hz}$, $\left.\mathrm{OCH}_{2}\right), 6.92(\mathrm{~s}, 1 \mathrm{H}, \mathrm{CH}), 7.47(\mathrm{t}, 1 \mathrm{H}, J=7.3 \mathrm{~Hz}, \mathrm{CH}), 7.50$ $(\mathrm{t}, 1 \mathrm{H}, J=8.0 \mathrm{~Hz}, \mathrm{CH}), 7.66(\mathrm{~d}, 1 \mathrm{H}, J=8.2 \mathrm{~Hz}, \mathrm{CH}), 7.70$ $(\mathrm{d}, 1 \mathrm{H}, J=8.5 \mathrm{~Hz}, \mathrm{CH}) .{ }^{13} \mathrm{C}$ NMR $\left(75 \mathrm{MHz}, \mathrm{CDCl}_{3}\right): \delta 14.0$ $(\mathrm{Me}), 61.9\left(\mathrm{OCH}_{2}\right), 110.9(\mathrm{C}), 122.6(\mathrm{CH}), 123.5(\mathrm{CH}), 125.1$ $(\mathrm{CH}), 126.1(\mathrm{CH}), 127.7(\mathrm{CH}), 128.7(\mathrm{C}), 133.1(\mathrm{C}), 140.1(\mathrm{CH})$, 

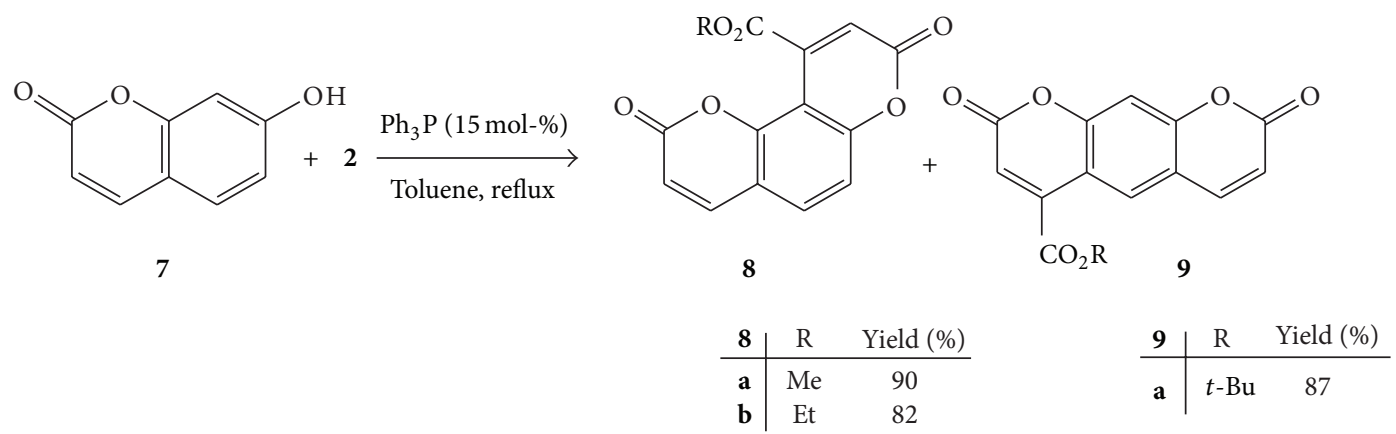

SCHeme 3: Procedure for synthesis of compounds $\mathbf{8}, \mathbf{9}$.

143.6 (C), 157.9 (C), 164.6 (C=O), 166.0 (C=O). MS (EI) $m / z$ : $296\left(\mathrm{M}^{+}, 10 \%\right), 277$ (100), 201 (43), 183 (52), 77 (68). Anal. calcd for $\mathrm{C}_{15} \mathrm{H}_{11} \mathrm{NO}_{4}$ : C, 66.91; $\mathrm{H}, 4.12 ; \mathrm{N}, 5.20$; Found: C, $66.94 ; \mathrm{H}, 4.10 ; \mathrm{N}, 5.21$.

Methyl 2,8-Dioxo-2H,8H-pyrano[3,2-g]chromene-4-carboxylate. Yellow powder, $0.50 \mathrm{~g}(90 \%) ; \mathrm{mp} 135-137^{\circ} \mathrm{C}$. IR (KBr) $\nu_{\max } / \mathrm{cm}^{-1}: 1739(\mathrm{C}=\mathrm{O}) ;{ }^{1} \mathrm{H} \mathrm{NMR}\left(300 \mathrm{MHz}, \mathrm{CDCl}_{3}\right): \delta 4.12$ (s, 3H, Me), 6.43 (d, 1H, J = 9.6 Hz, CH), $6.50(\mathrm{~s}, 1 \mathrm{H}, \mathrm{CH})$, $7.28(\mathrm{~d}, 1 \mathrm{H}, J=8.7 \mathrm{~Hz}, \mathrm{CH}), 7.66(\mathrm{~d}, 1 \mathrm{H}, J=8.7 \mathrm{~Hz}, \mathrm{CH})$, $7.72(\mathrm{~d}, 1 \mathrm{H}, J=9.6 \mathrm{~Hz}, \mathrm{CH}) .{ }^{13} \mathrm{C} \mathrm{NMR}\left(\mathrm{CDCl}_{3}\right) \delta / \mathrm{ppm} 53.8$, (OMe), $105.4(\mathrm{C}), 113.8(\mathrm{CH}), 114.9(\mathrm{C}), 115.2(\mathrm{CH}), 115.8$ (CH), $131.3(\mathrm{CH}), 142.9(\mathrm{CH}), 143.3(\mathrm{C}), 156.1(\mathrm{C}), 157.9(\mathrm{C})$, $158.3(\mathrm{C}=\mathrm{O}), 165.4(\mathrm{C}=\mathrm{O}), 167.6(\mathrm{C}=\mathrm{O}) ; \mathrm{MS}(\mathrm{EI}) \mathrm{m} / z: 272$ $\left(\mathrm{M}^{+}, 30 \%\right), 258$ (100), 231 (46), 146 (100). Anal. calcd for $\mathrm{C}_{14} \mathrm{H}_{8} \mathrm{O}_{6}$ : C, 61.77; H, 2.96; Found: C 55.96, H 3.09, N 4.88.

Ethyl 2,8-Dioxo-2H,8H-pyrano[3,2-g]chromene-4-carboxylate. Yellow powder, $0.38 \mathrm{~g}(67 \%) ; \mathrm{mp} 139-141^{\circ} \mathrm{C}$. IR ( $\left.\mathrm{KBr}\right)$ $\nu_{\max } / \mathrm{cm}^{-1}: 1728(\mathrm{C}=\mathrm{O}) ;{ }^{1} \mathrm{H}$ NMR $\left(300 \mathrm{MHz}, \mathrm{CDCl}_{3}\right): \delta 1.43$ $(\mathrm{t}, 3 \mathrm{H}, J=7.1 \mathrm{~Hz}, \mathrm{Me}), 4.35\left(\mathrm{q}, 2 \mathrm{H}, J=7.1 \mathrm{~Hz}, \mathrm{OCH}_{2}\right), 6.72$ $(\mathrm{d}, 1 \mathrm{H}, J=9.6 \mathrm{~Hz}, \mathrm{CH}), 6.95(\mathrm{~s}, 1 \mathrm{H}, \mathrm{CH}), 7.33$ (s, 1H, CH), $7.60(\mathrm{~d}, 1 \mathrm{H}, J=9.6 \mathrm{~Hz}, \mathrm{CH}), 8.55(\mathrm{~s}, 1 \mathrm{H}, \mathrm{CH}) .{ }^{13} \mathrm{CNMR}$ $\left(75 \mathrm{MHz}, \mathrm{CDCl}_{3}\right): \delta 14.0(\mathrm{Me}), 59.4\left(\mathrm{OCH}_{2}\right), 105.0(\mathrm{C}), 111.5$ $(\mathrm{CH}), 111.8(\mathrm{C}), 113.4(\mathrm{CH}), 115.0(\mathrm{CH}), 131.7(\mathrm{CH}), 142.2$ $(\mathrm{CH}), 143.7$ (C), 155.8 (C), 157.4 (C), $161.3(\mathrm{C}=\mathrm{O}), 165.9$ $(\mathrm{C}=\mathrm{O}), 167.5(\mathrm{C}=\mathrm{O})$; MS (EI) $m / z: 314\left(\mathrm{M}^{+}, 41 \%\right), 258$ (53), 231 (65), 170 (24). Anal. calcd for $\mathrm{C}_{15} \mathrm{H}_{10} \mathrm{O}_{6}: \mathrm{C}, 62.94 ; \mathrm{H}$, 3.52; Found: C, 62.97; H, 3.48.

Tert-butyl 2,8-Dioxo-2H,8H-pyrano[3,2-f]chromene-10-carboxylate. Yellow powder, $0.55 \mathrm{~g}(87 \%) ; \mathrm{mp} 150-152^{\circ} \mathrm{C}$. IR $(\mathrm{KBr}) v_{\max } / \mathrm{cm}^{-1}: 1747(\mathrm{C}=\mathrm{O}) ;{ }^{1} \mathrm{H} \mathrm{NMR}\left(300 \mathrm{MHz}, \mathrm{CDCl}_{3}\right)$ : $\delta 1.65(\mathrm{~s}, 9 \mathrm{H}, 3 \mathrm{Me}), 6.47(\mathrm{~d}, 1 \mathrm{H}, J=9.6 \mathrm{~Hz}, \mathrm{CH}), 6.96(\mathrm{~s}, 1 \mathrm{H}$, $\mathrm{CH}), 7.30$ (s, $1 \mathrm{H}, \mathrm{CH}), 7.78(\mathrm{~d}, 1 \mathrm{H}, J=9.6 \mathrm{~Hz}, \mathrm{CH}), 8.62(\mathrm{~s}$, $1 \mathrm{H}, \mathrm{CH}) .{ }^{13} \mathrm{C} \mathrm{NMR}\left(75 \mathrm{MHz}, \mathrm{CDCl}_{3}\right): \delta 29.3(3 \mathrm{Me}), 84.8(\mathrm{C})$, $105.2(\mathrm{C}), 113.7(\mathrm{CH}), 116.6(\mathrm{C}), 119.1(\mathrm{CH}), 127.3(\mathrm{CH}), 132.3$ $(\mathrm{CH}), 142.2(\mathrm{CH}), 142.9(\mathrm{C}), 155.9(\mathrm{C}), 156.1(\mathrm{C}), 159.4(\mathrm{C}=\mathrm{O})$, $162.5(\mathrm{C}=\mathrm{O}), 167.6(\mathrm{C}=\mathrm{O})$. MS (EI) $m / z: 314\left(\mathrm{M}^{+}, 41 \%\right), 277$ (25), 258 (64), 231 (33), 57 (100). Anal. calcd for $\mathrm{C}_{17} \mathrm{H}_{14} \mathrm{O}_{6}$ : C, 64.97; H, 4.49; Found: C, 64.95; H, 4.48.

\section{Result and Discussion}

Treatment of 4-hydroxyquinoline $\mathbf{1}$ with dialkyl acetylene dicarboxylate 2 and $\mathrm{PPh}_{3}$ in toluene under reflux afforded dimethyl 2-(4-hydroxy-2-methyl-3-quinolinyl)-2butenedioate (3) [22]. When compound 3 was heated at 200-205 $\mathrm{C}$ it transformed to methyl 2-oxo-2H-pyrano[3,2c]quinoline-4-carboxylate 4 in good yield. The analytical and spectral data of the product agree with the structure 4 suggested. The products were separated by column chromatography and identified as $\mathbf{4}$ based on their elemental analyses and their IR, ${ }^{1} \mathrm{H}$, and ${ }^{13} \mathrm{CNMR}$ spectral data. The mass spectra of these compounds displayed molecular ion peaks at appropriate $m / z$ values. Its ${ }^{1} \mathrm{H}$ NMR spectrum showed $3 \mathrm{H}$ singlet at $\delta=4.08$ for only one methoxy group and a singlet $(1 \mathrm{H})$ at $\delta=7.09$ for methine proton. The ${ }^{13} \mathrm{C}$ NMR spectrum one carbon appeared for the coumarin carbonyl $(\delta=158.6 \mathrm{ppm})$ and one carbon for the carbonyl ester moiety $(\delta=163.5 \mathrm{ppm})$. The ${ }^{1} \mathrm{H}$ and ${ }^{13} \mathrm{C} \mathrm{NMR}$ spectra of $\mathbf{4 b}$ and $\mathbf{4 c}$ are similar to those of $\mathbf{4 a}$ except for the alkoxy moieties, which exhibited characteristic resonances with appropriate chemical shifts.

Treatment of 3-isoquinolinol 5 with dialkyl acetylene dicarboxylate 2 and $\mathrm{PPh}_{3}$ in refluxing toluene for $24 \mathrm{~h}$ and separation of the reaction mixture by column chromatography gave methyl 3-oxo-3H-pyrano[2,3-c] isoquinoline-1carboxylate 6 in $76 \%$ yield (Scheme 3), obviously via a reaction sequence similar to that depicted in Scheme 1. The reaction with di-tert-butyl acetylene dicarboxylate was not detected because of the bulky group (Scheme 2).

Next, we studied the reaction of 7-hydroxy coumarine 7 with dialkyl acetylene dicarboxylate and $\mathrm{PPh}_{3}$ in refluxing toluene, which resulted in the formation of the methyl 2,8-dioxo-2H,8H-pyrano[3,2-g]chromene-4-carboxylate $\mathbf{8}$ (Scheme 3). The linear product 9 was detected and isolated from the reaction with di-tert-butyl acetylene dicarboxylate because of the bulky group.

Mechanistically $[13,19]$ it is conceivable that the reaction involves the initial formation of a zwitterionic intermediate between $\mathrm{Ph}_{3} \mathrm{P}$ and the acetylenic compound and subsequent protonation of reactive $1: 1$ adduct followed by electrophilic attack of vinyltriphenylphosphonium cation on the aromatic 


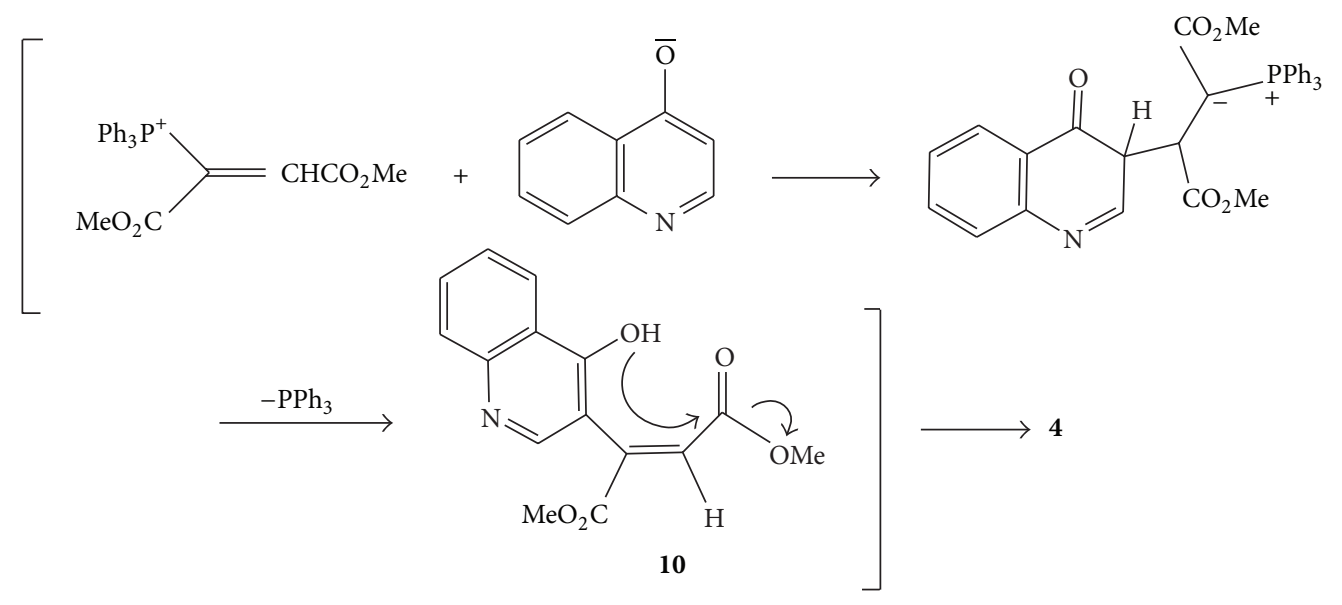

SCHEMe 4

ring at the ortho position relative to the strong activation group. The product is presumablyproduced by intramolecular lactonization of the unsaturated diester $\mathbf{1 0}$ (Scheme 4).

\section{Conclusion}

From the above results, we conclude that treatment of oxygen atom of the pyran ring belongs to the starting phenol, while the periselectivity in the construction of this new ring depends on the higher reactivity of the free o-positions of the phenol during the aromatic electrophilic substitution sequence. These functionalised coumarins may be considered as potentially useful synthetic intermediates because they possess atoms with different oxidation states. The advantages of present method are the fact that it performed under neutral condition and substances are utilized in their basic form without any modification. The simplicity of the present procedure makes it an interesting alternative to other approaches.

\section{Acknowledgment}

The authors thank the Karaj Branch, Islamic Azad University, for support of this work.

\section{References}

[1] R. D. Murray, J. Mendez, and S. A. Brown, The Natural Coumarins: Occurrence, Chemistry and Biochemistry, John Wiley \& Sons, 1982.

[2] F. A. Jiménez-Orozco, J. A. Molina-Guarneros, N. MendozaPatiño et al., "Cytostatic activity of coumarin metabolites and derivatives in the B16- F10 murine melanoma cell line," Melanoma Research, vol. 9, no. 3, pp. 243-247, 1999.

[3] G. J. Finn, B. Creaven, and D. A. Egan, "Study of the in vitro cytotoxic potential of natural and synthetic coumarin derivatives using human normal and neoplastic skin cell lines," Melanoma Research, vol. 11, no. 5, pp. 461-467, 2001.

[4] D. Yim, R. P. Singh, C. Agarwal, S. Lee, H. Chi, and R. Agarwal, "A novel anticancer agent, decursin, induces G1 arrest and apoptosis in human prostate carcinoma cells," Cancer Research, vol. 65, no. 3, pp. 1035-1044, 2005.

[5] M. E. Riveiro, R. Vazquez, A. Moglioni et al., "Biochemical mechanisms underlying the pro-apoptotic activity of 7,8dihydroxy-4-methylcoumarin in human leukemic cells," Biochemical Pharmacology, vol. 75, no. 3, pp. 725-736, 2008.

[6] I. Kostova, S. Raleva, P. Genova, and R. Argirova, "Structureactivity relationships of synthetic coumarins as HIV-1 inhibitors," Bioinorganic Chemistry and Applications, vol. 2006, Article ID 68274, 9 pages, 2006.

[7] B. F. Gage, "Pharmacogenetics-based coumarin therapy," Hematology, vol. 2006, no. 1, pp. 467-473, 2006.

[8] D. A. Ostrov, J. A. Hernández Prada, P. E. Corsino, K. A. Finton, N. Le, and T. C. Rowe, "Discovery of novel DNA gyrase inhibitors by high-throughput virtual screening," Antimicrobial Agents and Chemotherapy, vol. 51, no. 10, pp. 3688-3698, 2007.

[9] R. M. Melavanki, R. A. Kusanur, M. V. Kulakarni, and J. S. Kadadevarmath, "Role of solvent polarity on the fluorescence quenching of newly synthesized 7,8-benzo-4-azidomethyl coumarin by aniline in benzene-acetonitrile mixtures," Journal of Luminescence, vol. 128, no. 4, pp. 573-577, 2008.

[10] T. Z. Yu, P. Zhang, Y. L. Zhao, H. Zhang, J. Meng, and D. W. Fan, "Synthesis and photoluminescent properties of two novel tripodal compounds containing coumarin moieties," Spectrochimica Acta A, vol. 73, no. 1, pp. 168-173, 2009.

[11] H. Turki, S. Abid, S. Fery-Forgues, and R. El Gharbi, "Optical properties of new fluorescent iminocoumarins: part 1," Dyes and Pigments, vol. 73, no. 3, pp. 311-316, 2007.

[12] X. Li, Y. X. Zhao, T. Wang, M. Q. Shi, and F. P. Wu, "Coumarin derivatives with enhanced two-photon absorption cross-sections," Dyes and Pigments, vol. 74, no. 1, pp. 108-112, 2007.

[13] I. Yavari, R. Amiri, and M. Haghdadi, "Triphenyphosphinemediated efficient synthesis of functionalized 2-OXO-2HChromenes," Phosphorus, Sulfur and Silicon and the Related Elements, vol. 179, no. 11, pp. 2163-2168, 2004.

[14] E. Galariniotou, V. Fragos, A. Makri, K. E. Litinas, and D. N. Nicolaides, "Synthesis of novel pyridocoumarins and benzofused 6-azacoumarins," Tetrahedron, vol. 63, no. 34, pp. 82988304, 2007. 
[15] S. D. Kudale and M. N. Deodhar, "Synthesis and evaluation of some coumarin containing potential antimicrobial agents," Journal of Chemistry, vol. 9, no. 4, pp. 2493-2500, 2012.

[16] M. A. Hosny, M. A. Radwan, and E. A. El-Sawy, "Synthesis and anticancer activity of some new derivatives of coumarin and quinolinyl mercaptotriazoles," Journal of Chemistry, vol. 9, no. 4, pp. 1737-1745, 2012.

[17] D. Kini and M. Ghate, "Synthesis and oral hypoglycemic activity of 3-[5'-Methyl-2' - aryl-3' -(thiazol-2' -yl amino) thiazolidin$4^{\prime}$-one]coumarin Derivatives," Journal of Chemistry, vol. 8, no. 1, pp. 386-390, 2011.

[18] J. L. Du, L. I. Li, and D. H. Zhang, "Ultrasound promoted synthesis of 3-carboxycoumarins in aqueous media," Journal of Chemistry, vol. 3, p. 1, 2006.

[19] B. Mohtat, I. Yavari, R. E. Ameri, and E. Salahia, "Synthesis of aza coumarines by nucleophilic addition of acetylenic esters catalysed by $\mathrm{Ph}_{3}$ P," Croatica Chemica Acta, vol. 84, no. 1, pp. 123126, 2011.

[20] B. Mohtat, S. Azimzadeh, H. Djahaniani, and L. Pirhadi, " $\mathrm{Ph}_{3} \mathrm{P}$ catalyzed synthesis of alkyl 2-(4-oxopyridin-1 $(4 \mathrm{H})$ - $\mathrm{Yl}$ ) acrylates by nucleophilic addition to alkyl propiolates," South African Journal of Chemistry, vol. 63, pp. 204-206, 2010.

[21] B. Mohtat, Z. N. Azar, S. Nahavandian, H. Djahaniani, and A. Ahmadi, "Synthesis of dialkyl 2-(4-oxopyridin-1 $(4 \mathrm{H})$ yl)dicarboxylates through the reaction of 4-hydroxypyridine and dialkyl acetylenedicarboxylate in the presence of triphenylphosphine," Journal of the Mexican Chemical Society, vol. 55, no. 3, pp. 194-196, 2011.

[22] B. Mohtat, S. Nahavandian, N. Z. Azar, H. Djahaniani, and Z. Hossaini, "Triphenylphosphine-promoted c-vinylation of 4hydroxyquinolines," Zeitschrift fur Naturforschung, vol. 66, no. 7, pp. 700-704, 2011. 

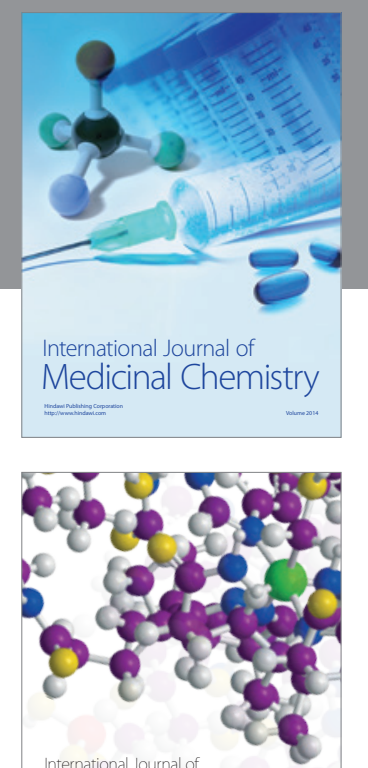

\section{Carbohydrate} Chemistry

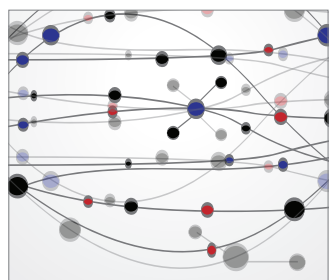

The Scientific World Journal
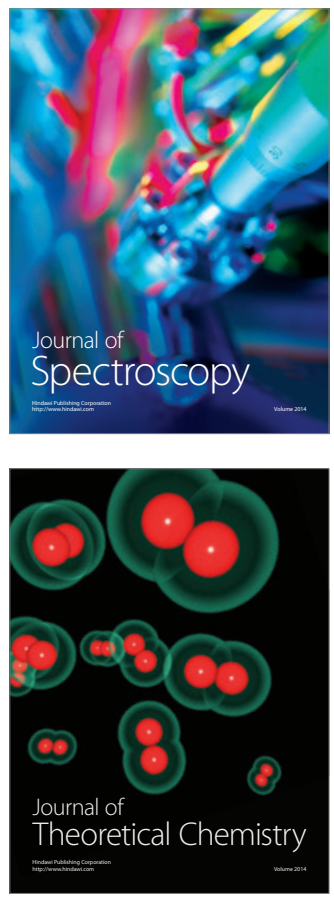
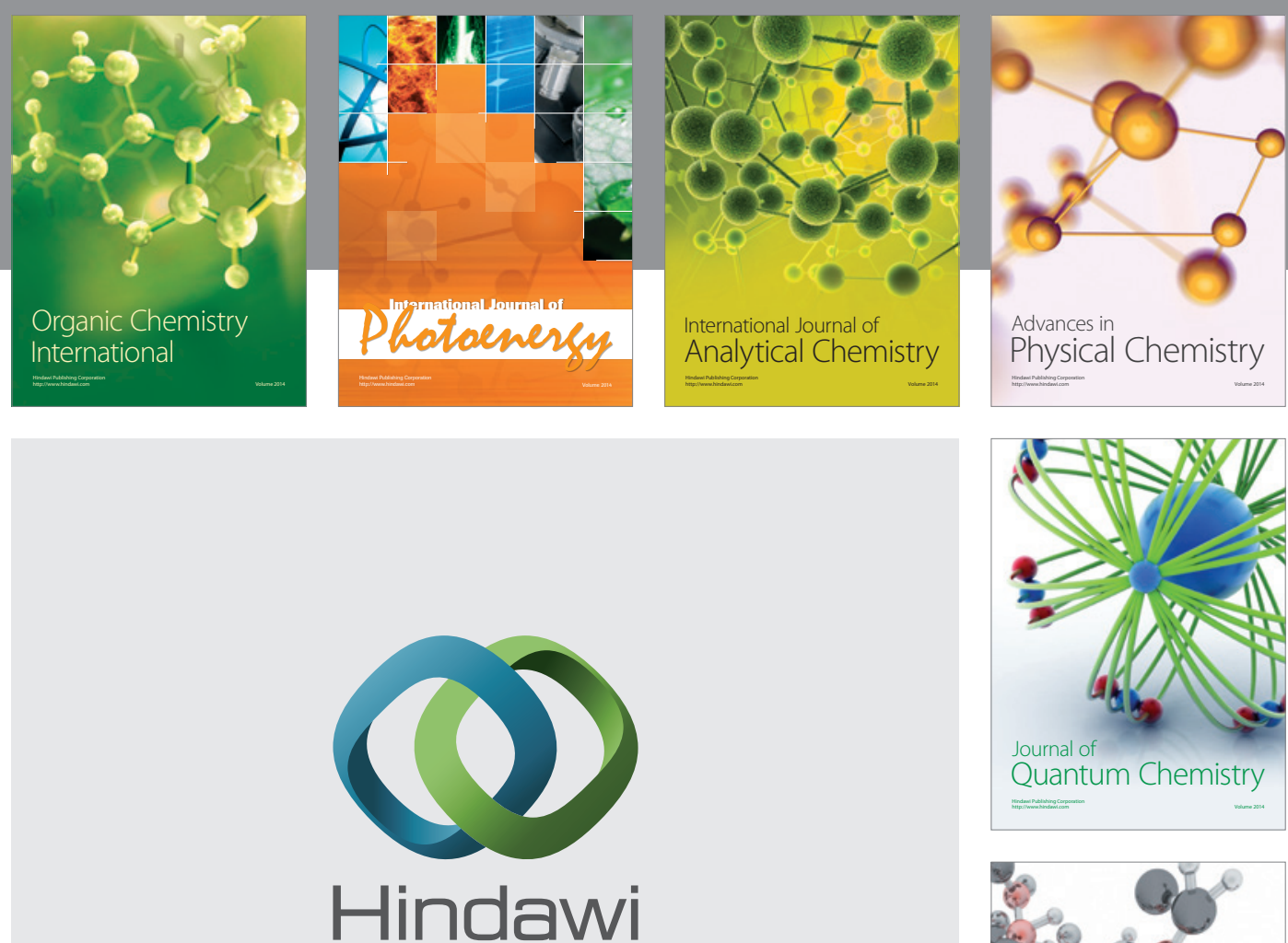

Submit your manuscripts at

http://www.hindawi.com

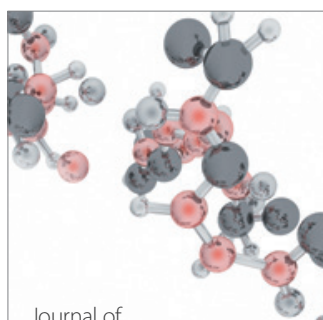

Analytical Methods

in Chemistry

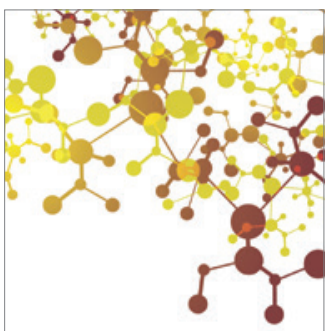

Journal of

Applied Chemistry

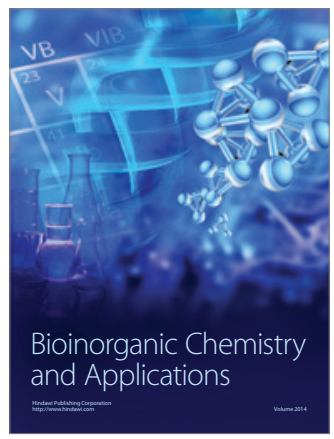

Inorganic Chemistry
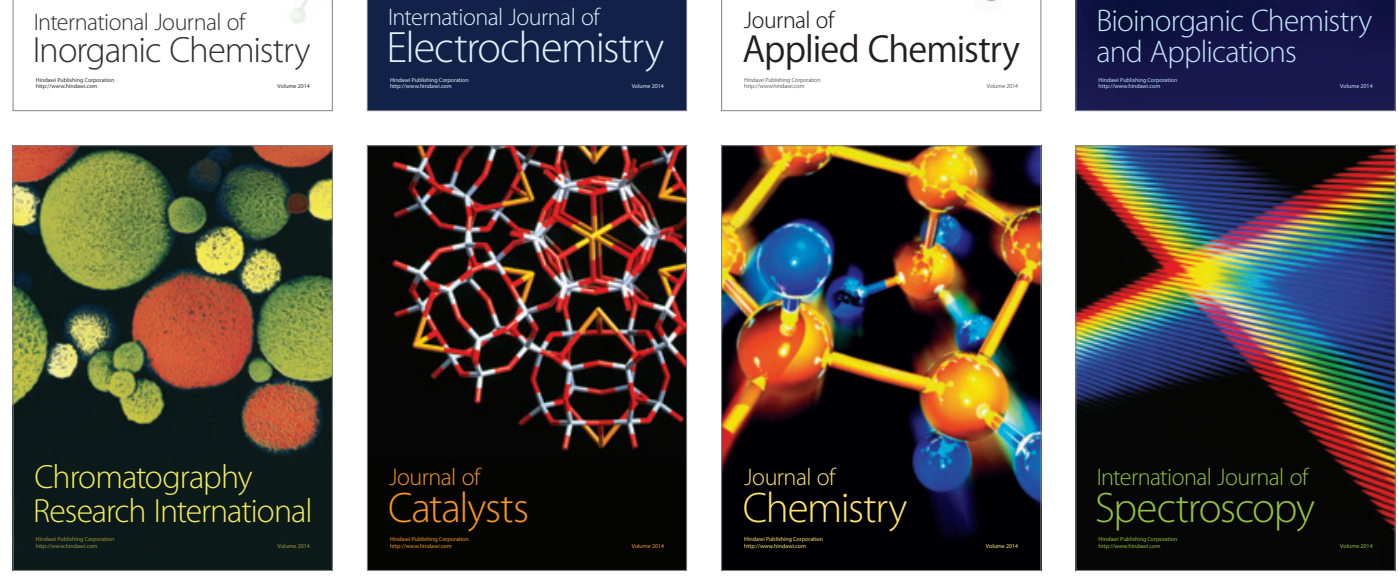